\title{
A STUDY OF THE EFFICIENCY OF GROUPS OF EX-MINERS DISABLED BY PNEUMOCONIOSIS EMPLOYED IN LIGHT INDUSTRIES IN SOUTH WALES
}

\author{
BY \\ J. A. P. TREASURE \\ From the Pneumoconiosis Research Unit of the Medical Research Council
}

In order to compare the efficiency of disabled men suffering from coal miners' pneumoconiosis with corresponding groups of other workers, two methods of approach were used: an objective approach, comparing the efficiency of a disabled group directly with a corresponding group of fit workers; and a subjective approach, obtaining the opinions of employers about the performance of the disabled men.*

The objective method immediately revealed two problems. First, what index could be used to measure " efficiency"; and, secondly, how could "ex-miners disabled by pneumoconiosis" be defined ? The efficiency of a certain type of labour can be measured most directly by output. Unfortunately, in this case it was not possible to use output as a measure of the efficiency of the disabled men, because of the lack, at the time of the enquiry, of firms in South Wales employing a considerable number of such men on individual piece-rates. Where piece-rates were paid, they were group piece-rates, and although some disabled men may have been included in the group, output could not be attributed to individuals. Most of the disabled men in South Wales were employed on jobs, such as store-keeping and labouring, where they were only indirectly productive. Consequently, other less direct measures had to be used. Absence from work, labour turnover, and accident rates can all be used as less direct quantitative measures of " effciency". In the objective part of this investigation absence from work has been used as the measure of efficiency. There is, of course, no necessary connexion between absence and efficiency on the job, but the two are probably inversely related. The nature of the data available prevented the use of labour turnover or industrial accidents as other measures of efficiency.

* The term " disabled men" in this study will henceforth be used as a brief description of ex-miners certified as disabled by pneumoconiosis, except where otherwise stated.
For the purpose of this study some clear-cut distinction had to be drawn between men disabled by pneumoconiosis and all other men. The former were defined as those men who had been certified by the Silicosis Medical Board. All other men were regarded as being "fit". In view of the fact that in the early stages of pneumoconiosis there may be some uncertainty in diagnosis it is possible that in some cases this definition may have been somewhat arbitrary. Nevertheless a line had to be drawn somewhere, and certification had the merit of being precise from the social, if not from the medical, point of view.

There is one important corollary to this definition of disabled men. Pneumoconiosis cases constitute such a heterogeneous group as far as age and physical disability are concerned, that one might expect the efficiency and absenteeism of such men to vary considerably. However, since we are only concerned here with men employed in light industry, we are dealing with a more homogeneous group than the general population of disabled men, since it is probable that the employers would only take on the fitter men.

\section{Collection of Data}

Absence Records.-Despite the fact that there are a large number of certified disabled men employed in industry in South Wales, their industrial distribution is so widespread that the men selected for this investigation were all factory workers employed in light industry, for it proved impossible to find groups of sufficient size in other types of employment.

The most obvious method of finding these men in industry was to ask their employers. Unfortunately, in many cases, employers did not know which of their employees were disabled by pneumoconiosis. The men concerned were sometimes very reluctant to reveal their disability because they believed that they would be dismissed if identified as cases of pneumoconiosis. In a factory in 
Monmouthshire, for example, the labour manager said that as far as he knew there were no disabled men employed in the factory, yet the factory policeman, in conversation, said that there were several such cases actually in employment there. The fact that many of these men remained unremarked was an indirect testimonial to their working capacity but it made their identification a difficult, and sometimes highly delicate, task.

A second method of finding these men was provided by the sample inquiries carried out in 1946 by the Social Survey (1946) and Medical Research Council (Stewart, 1948). These samples supplied the names both of the men and of their current employers. Lists of names were extracted from these samples and the corresponding employers visited.

A third method was used in one factory where the entire labour force was interviewed on the job. The information obtained in this way was reliable, but for obvious reasons this direct method could be used only in special circumstances.

Only in three factories were enough disabled men found in employment to warrant study. In two of them, Factory 1 and Factory 2, the absence records of the disabled men were compared with a corresponding control group of "fit" men. In the third, Factory 3, only the absence records of the disabled men were obtained as it was not possible to select a control group there.

The precise data obtained at these factories are as follows:

In Factory 1 the time lost through absence by each of 37 disabled men employed in 1946, 60 employed in 1947, and 69 employed in 1948 was obtained and compared with the time lost by a corresponding control group of fit men* selected so as to have the same distribution within the group of age, length of employment, and working experience. Consequently, it is hoped that pneumoconiosis constitutes the only essential difference between the disabled and fit groups.

In Factory 2 the absence records in 1948 of 26 disabled men ("disabled group") were compared with those of a corresponding group of 98 fit men (" control group ") from whom were selected, on the same basis as in the case of Factory 1, a true control group of 26 men (" selected controls"). Also, in this factory the absence records of 72 men who had disabilities other than pneumoconiosis were obtained ("disabled controls"), and from these again a true control group of 26 men (" selected disabled controls") was selected on the same basis as before. In this way the absence records of

* There were more men in the control than in the disabled group in 1946 but equal numbers in 1947 and 1948. The discrepancy occurs in 1946 because, although there were originally equal numbers in the two groups, the material had to be re-analysed and completed in 1949 by which time some of the factory records were missing. The remaining groups were still well enough balanced for this not to affect comparisons between the groups. pneumoconiosis cases were compared with those of other disabled men.

In Factory 3 only the absence records of 53 men disabled by pneumoconiosis were obtained.

To make sure that previous mining experience, apart from pneumoconiosis, was not a factor affecting absence from work, a group of ex-miners, none of whom had been certified by the Silicosis Medical Board, were also studied. At a store depot, 41 ex-miners who had not been certified as having pneumoconiosis were employed and their sickness absence in 1948 was compared with a selected control group of 41 other workers.

Employers' Opinions.- The opinions of employers concerning the efficiency of the disabled men they had employed, or were still employing, were obtained from a questionnaire sent to 150 firms in South Wales. Besides this, it was found that one firm in South Wales, which employed a number of disabled men, kept careful subjective estimates of the efficiency of all its employees. This firm kindly provided these records for some of its workers, and the opinions of the efficiency of the 24 disabled men in employment have been recorded and compared with the opinions about a corresponding control group of fit men.

\section{RESULTS}

Absence from Work.-Before considering the periods of absence found for the different groups of men in the four places investigated, the definition of " absence" must be made clear. It was found that all the factories concerned kept their absence records under three main headings: (1) sickness absence, by which is meant absence covered by medical certificate; (2) unauthorized absence, by which is meant absence without satisfactory reason being given; and (3) authorized absence, by which is meant absence permitted by the factory for reasons other than sickness.

Authorized absence, as defined, was found to be $\frac{D}{O}$ of negligible importance so that in the tables of results only sickness absence and unauthorized $N$ absence have been recorded.

As the absence records of different groups of workers in the four places of employment are to be compared one with the other, it is important that the conditions under which the different groups of men worked were found to be very similar, both $\mathbb{D}$ within and between each place. Likewise, the duration of employment of the men in the various groups was found not to differ greatly. In 1948 all four places of employment worked a five-day week of 44 hours and so again they were comparable. Lastly, the age distributions of the various groups 
of men were taken into account and made comparable at the time of the selection of the cases.

The absence records of the different groups of workers in the four factories will now be considered individually.

The distribution of the percentage of time at risk which was lost by the disabled and the control groups at Factory 1 is shown in Table $I$.

In Table $I$ and in all subsequent tables the time at risk is the total number of shifts that occurred during the period of study, less the number lost by any form of absence other than that under consideration. For example, the time at risk when considering " unauthorized absence" in Table $I$ is the number of shifts worked during the periods shown in each column less absence caused by authorized vacations and sickness absence.

It will be seen from Table I that the differences between the distributions of sickness absence and unauthorized absence; for both disabled and the control groups, are very small and it is probable that they would be thought of no account by an employer. The average percentage of time lost through sickness absence was smaller in the disabled group than in the controls in each year. The average percentage of time lost through unauthorized absence was, however, greater in the disabled group each year, the maximum difference being 0.61 in 1946. The statistical significance of the difference between these mean percentages may be tested, despite the forms of the distributions, by a method devised by Pitman (1937). By a suitable transformation each comparison can be made to give a value for "Student's " statistic " $t$," which gives, in its turn, the probability of differences as great or greater than those being found by a random

TABLF I

Frequency Distribution of Percentage of Time at Risk lost through Unauthorized and Sickness Absence by Groups of Disabled Men and Control.s in Factory 1

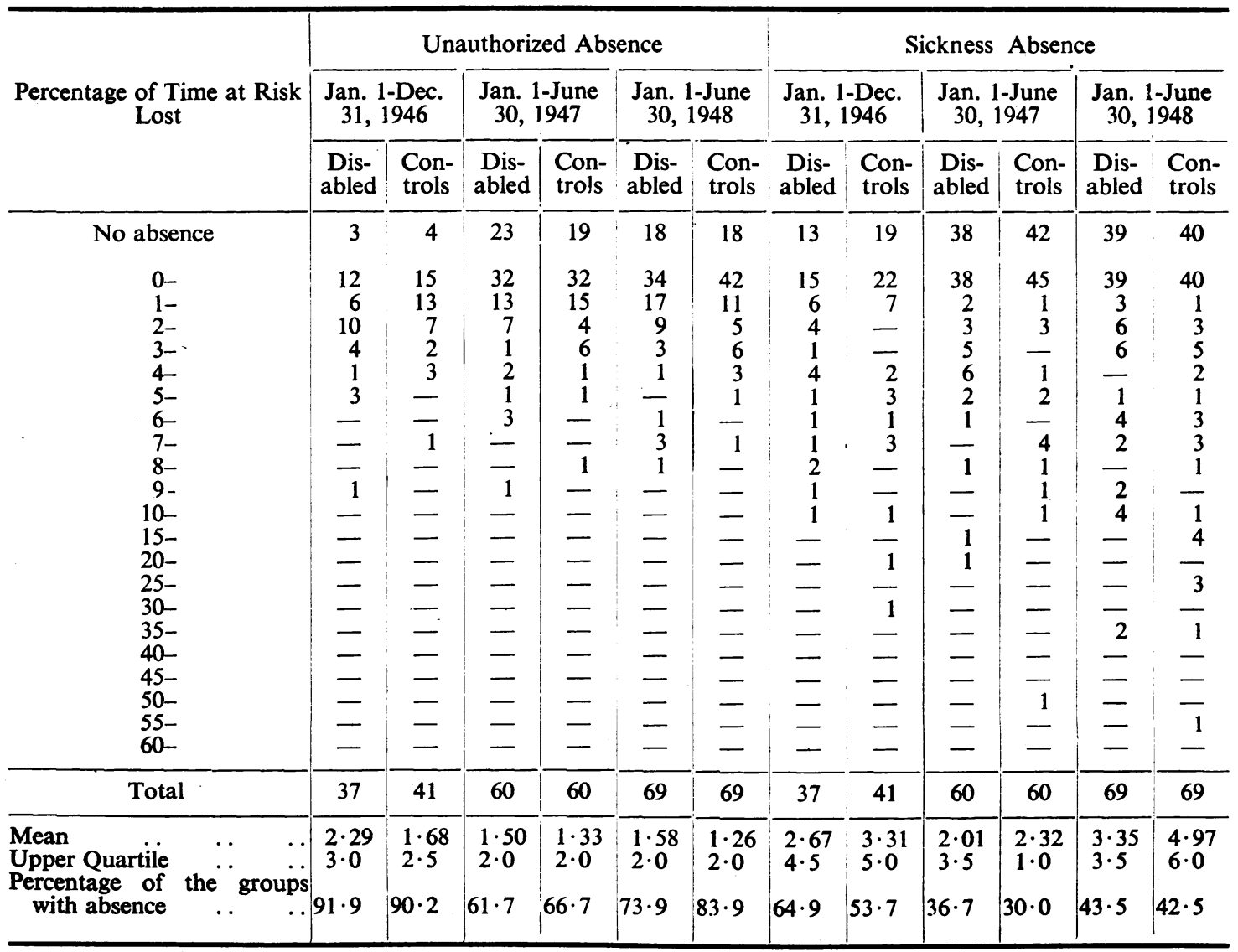


dichotomy of the aggregated group of disabled and controls. These probabilities are given in Table II.

The probabilities given in Table II are relatively large so that the differences found may well have occurred by chance, and the groups, therefore, may not be differentiated by their absence from work. Since, however, the disabled men have a higher unauthorized absence and a lower sickness absence than the fit men in every year (Table I), is the probability of this repeated bias likely to have arisen by chance ? The probabilities of such differences of the given sign can be combined to give a value of $\chi^{2}$ which can be tested in the usual way.

For sickness absence the value of $\chi^{2}$ is $8 \cdot 25$, which for 6 degrees of freedom, has a probability of between $0 \cdot 2$ and $0 \cdot 3$. For unauthorized absence $\chi^{2}$ is 11.63 , and the probability lies between 0.05 and $0 \cdot 1$. Thus, in neither case does the persistence of the pattern of absence over three years make the difference significant.
It may be argued that the mean percentage of $\frac{1}{0}$ absence is not the most useful measure to use, since the employer of labour will wish to know something of the range of absence he may expect. The uppero quartile, to the nearest half per cent., of eacho distribution has, therefore, been given in addition. $\frac{\bar{p}}{\bar{D}}$ This is the percentage of absence which 75 per cent. $\Phi$ of the men in each group did not exceed, and it provides, consequently, a measure of the greatest ${ }^{\text {s }}$ probable absence-rate shown by a majority of them. The use of the upper quartile as a measure of $\overrightarrow{\vec{\omega}}$ dispersion is arbitrary, but it was chosen as being ${ }^{\omega}$ convenient in this case. From the upper quartiles $\mathbb{D}$ given in Table $I$ it will be seen that in the case of? unauthorized absence there was no difference $\omega$ between the disabled and the controlled groups,, $\overrightarrow{.}$ except in 1946, and in the case of sickness absence $N$ the disabled men did better than the fit men in two 윽 of the years though worse in the third. In every case the differences between the quartiles are small.

\section{TABLE II}

Results of Tests of Significance on the Differences between the Percentages of Time at Risk lost through AbSence by Various Groups OF Men in the Different Factories

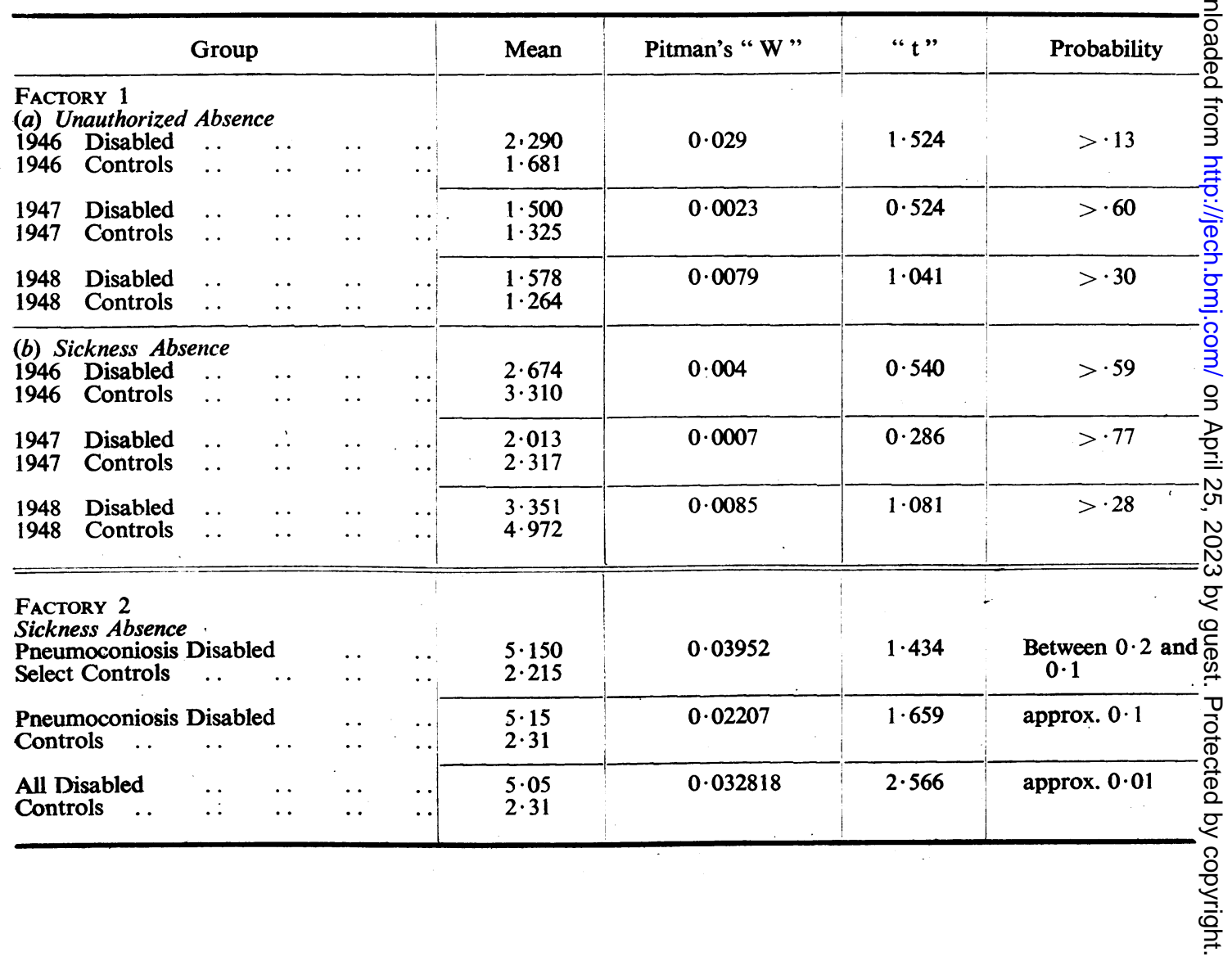


Although the means and upper quartiles of the distributions of percentage absence have been found to be very similar in both the fit and disabled groups, it is possible that a similar total amount of absence could have arisen, in one group through many short absences, and in the other through few long absences. The data from Factory 1 in 1946 was analysed from this point of view, and Table III shows the duration of absence, measured by the number of consecutive shifts lost, that occurred in the two opposed groups.

\section{TABLE III}

Frequency Distribution of Number of CONSECutive Work ShIFTs lost by Disabled Men and Controls, FACTORY 1, JAN. 1 - DeC. 31, 1946

\begin{tabular}{|c|c|c|c|c|}
\hline \multirow{2}{*}{$\begin{array}{l}\text { No. of } \\
\text { Consecutive } \\
\text { Shifts Lost }\end{array}$} & \multicolumn{2}{|c|}{$\begin{array}{l}\text { Unauthorized } \\
\text { Absence }\end{array}$} & \multicolumn{2}{|c|}{$\begin{array}{l}\text { Sickness } \\
\text { Absence }\end{array}$} \\
\hline & Disabled & Controls & Disabled & Controls \\
\hline $\begin{array}{r}\frac{1}{2} \\
1 \\
2 \\
3 \\
4 \\
5 \\
5 \\
6 \\
7 \\
8 \\
9 \\
9 \\
10 \\
11 \\
12 \\
13 \\
14 \\
15- \\
20- \\
25- \\
30- \\
35- \\
40- \\
45- \\
50-\end{array}$ & $\begin{array}{r}11 \\
198 \\
16 \\
2 \\
2 \\
-1 \\
= \\
= \\
= \\
= \\
= \\
= \\
= \\
= \\
= \\
= \\
-\end{array}$ & $\begin{array}{c}12 \\
152^{*} \\
10 \\
4 \\
-1 \\
= \\
= \\
= \\
= \\
= \\
= \\
= \\
= \\
= \\
= \\
= \\
=\end{array}$ & $\begin{array}{r}-4 \\
5 \\
9 \\
-8 \\
4 \\
5 \\
5 \\
\frac{5}{3} \\
1 \\
1 \\
3 \\
= \\
2 \\
1 \\
- \\
= \\
= \\
-\end{array}$ & $\begin{array}{r}-4 \\
9 \\
3 \\
7 \\
7 \\
6 \\
1 \\
1 \\
1 \\
2 \\
2 \\
4 \\
1 \\
1 \\
2 \\
1 \\
- \\
2 \\
-\end{array}$ \\
\hline $\begin{array}{l}\text { Mean Length } \\
\text { of Absences } \\
\text { Mean No. of } \\
\text { Absences } \\
\text { No. of Men }\end{array}$ & $\begin{array}{c}1 \cdot 11 \\
6 \cdot 22 \\
37\end{array}$ & $\begin{array}{c}4 \cdot 37 \\
41\end{array}$ & $\begin{array}{c}1 \cdot 38 \\
37\end{array}$ & $\begin{array}{c}8 \cdot 13 \\
1 \cdot 32 \\
41\end{array}$ \\
\hline
\end{tabular}

* Including one absence of $1 \frac{1}{2}$ shifts.

From Table III the distributions in the two groups are again seen to be very similar. The mean lengths of unauthorized absences were 1.11 shifts for disabled men and 1.09 shifts for fit men, and for sickness absence the means were 5.88 shifts and 8.13 shifts respectively, so that again, where sickness is concerned, the disabled group did slightly better than the controls. When the mean number of absences is compared, we find no difference between the groups in sickness absence, but a difference in favour of the fit men of nearly two shifts in the mean number of unauthorized absences. (This figure is, of course, related to the mean absence-rate previously obtained; an absence of one shift corresponds roughly to a rate of 0.3 per cent.)

We conclude on this limited evidence, that the slightly smaller sickness absence rate of the disabled men is the result of a total number of absences equal to those shown by the fit men but shorter in duration. The slightly higher unauthorized absence rate of the disabled is due to a larger number of absences of duration equal to those of the fit men. It will be realized that on the whole the number of absences will be of more interest to an employer than the duration of absence, since alternative arrangements must be made whether a man is absent for one shift or eight. The differences are so small, however, that no great significance can be attached to them. It was not considered worth while analysing the data for 1947 and 1948 in this way.

The employee who loses no time at all is obviously ideal as far as absence is concerned, so that the proportion of a group of workers who have periods of absence will be a measure of the deviation of this group from the ideal. From Table I once again it will be seen that the two groups of men did not differ significantly, as far as this measure was concerned, in the three years in which we have observed them.

It might well be that the absence records of certified men disabled by pneumoconiosis would be affected by the amount and kind of compensation they were receiving. Consequently, the group of disabled men in this factory was sub-divided into two groups comprising (1) those in receipt of weekly compensation, and (2) those who had settled their claim to compensation by taking a lump payment. These two groups are compared in Table IV (overleaf).

Here the numbers in the total column do not add up to the totals for disabled given in Table I. This discrepancy arises because some men settled their claim to compensation during the period of observation and, as a result, could not fairly be classified into either of the two sub-groups and have therefore been rejected: It will be seen from Table IV that the mean percentage of the time at risk which was lost through unauthorized absence is similar in both groups for each year. On the other hand, the mean percentage of time at risk lost through sickness absence is higher for the group of 
TABLE IV

Comparison of Frequency Distribution of Percentage of Time at Risk lost through Unauthorized and Sickness Absence in Factory 1 by Disabled Men on Weekly Compensation and "Settled " Compensation

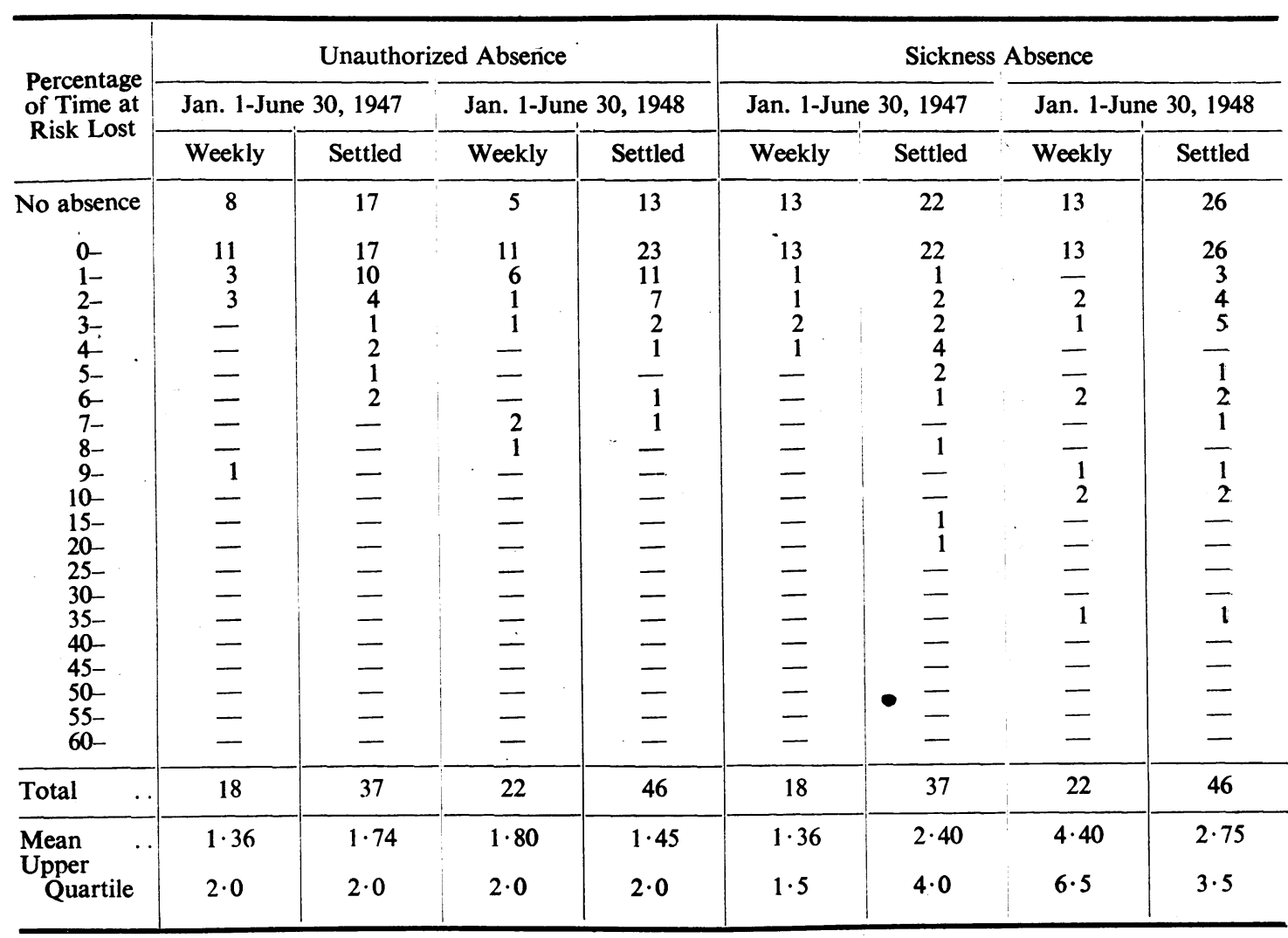

disabled workers who were in receipt of weekly compensation than for the corresponding group who had " settled" their claim in 1948, but it is lower in 1947.

In this factory the number of occasions on which a man was late and the number of minutes late were also studied; but, for this purpose, only data taken in 1946 were available. These are presented in Table V.

The effects of a strike, which caused 32 of the disabled and 30 of the controls to be "late" for 150 minutes and one further man from each group to be late 420 minutes, have been neglected. The average number of days on which men were late was 3.3 in the year both for the fit and the disabled group. Of those who were late, the average number of minutes lost was 19.44 for the fit group and 24.96 for the disabled. There is thus no evidence that the disabled men were more often late, nor, when they were late, were they many minutes later than the controls.

TABLE V

Frequency Distribution of Degree of LATENess of $\frac{\circ}{5}$ DISABLED MEN COMPARED WITH CONTROLS IN FACTORY 1, I JAN. 1-DEC. 31, 1946

\begin{tabular}{|c|c|c|}
\hline $\begin{array}{l}\text { No. of Minutes } \\
\text { Late }\end{array}$ & Disabled & Controls \\
\hline $\begin{array}{c}1- \\
30- \\
60- \\
90- \\
120-150\end{array}$ & $\begin{array}{r}111 \\
9 \\
1 \\
1 \\
-\end{array}$ & $\begin{array}{r}106 \\
22 \\
2 \\
2 \\
2\end{array}$ \\
\hline $\begin{array}{l}\text { Mean No. of } \\
\text { Minutes Late } \\
\text { Mean No. of } \\
\text { Times Late } \\
\text { No. of Men }\end{array}$ & $\begin{array}{c}19 \cdot 44 \\
3 \cdot 3 \\
37\end{array}$ & $\begin{array}{c}24 \cdot 96 \\
3 \cdot 3 \\
41\end{array}$ \\
\hline
\end{tabular}


In Factory 3 only disabled men were studied. Their sickness absence in 1948 is given in Table VI.

TABLE VI

Frequency Distribution of Percentage of Time at RISK LOST THROUGH UNAUTHORIZED AND SICKNESS Absence by Disabled Men in Factory 3, Jan. 1JUNE 30, 1948

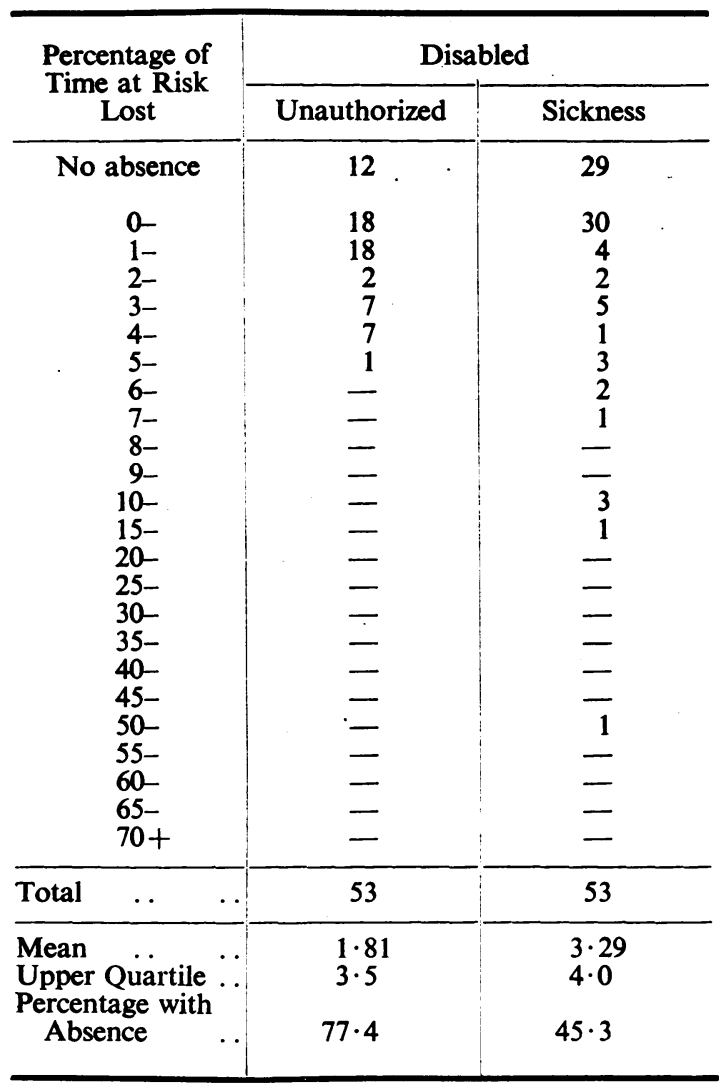

By comparing Table VI with Table I it will be seen that both the means and the upper quartiles of the absence records are of the same order of magnitude. We may presume, therefore, that Factory 1, in which the more detailed investigation was made, was unlikely to be a special case in relation to the absence records of disabled men.

The absence records of all the groups of men studied in Factory 2 are given in Table VII (overleaf). When we compare the sickness absence records of the pneumoconiosis cases ("pneumoconiosis disabled ") with the corresponding group of fit men (" selected controls") we find that the mean. percentage of time at risk lost by the disabled men is almost twice as great as that lost by the control group. The significance of this difference was tested (see Table II) but it was found that a difference of this size could have occurred by chance. Thus, in this factory again, we find that the sickness absence rate of the disabled men did not differ significantly from that of the normal worker; but the groups observed were very small and the absolute difference in sickness absence between them was large. The small number, therefore, may have been the reason why this difference was not statistically significant.

The distributions of time lost through sickness absence of the pneumoconiosis cases were compared with a control group of other disabled workers ("selected disabled controls") and it was found that neither the mean percentage of time lost nor the upper quartiles differed greatly.

Furthermore, the pneumoconiosis cases hardly differed in their sickness absence records from the group of other disabled workers (" disabled controls").

It was therefore concluded that men with pneumoconiosis were not differentiated in Factory 2 in their sickness absence records from men suffering from other forms of disability. However, in order to test the notion that the insignificant difference between the absence records of pneumoconiosis cases compared with fit workers might have been due to the small numbers concerned, as discussed above, the absence records of the pneumoconiosis disabled men were combined with those of all other disabled workers ("disabled controls") and the performance of the total disabled group obtained was compared with the performance of all the fit men. When this was done it was found that the disabled men had significantly more sickness absence than the fit workers (see Table II).

This procedure of combining the records of the pneumoconiosis cases with those of all other disabled workers cannot be fully justified; nevertheless, it does suggest that the insignificant difference found between the performance of the pneumoconiosis cases compared with the performance of the fit workers might well have been due to the small numbers in the groups.

The results obtained from the investigation in a Store Depot indicated that previous mining experience, apart from pneumoconiosis, was not a factor affecting absence from work. For it will be seen from Table VIII (overleaf) that the mean percentages of the time at risk lost by a group of ex-miners without pneumoconiosis compared with a control group of non-miners did not differ greatly; likewise, neither did the upper quartile distributions nor the percentage of workers who had periods of absence differ markedly. 
Summary of Findings on Absence Data.-It may be convenient at this point to summarize the main findings from the absence data presented above.

In neither Factory 1 nor in Factory 2 were groups of pneumoconiosis cases found to have significantly more sickness or unauthorized absence than corresponding control groups of normal workers. In Factory 2 the sickness absence of the disabled men was greater than that of the fit men, but in Factory 1 the disabled men had actually less sickness absence over a period of three years.

A group of 53 men at Factory 3 had much the same absence records as the disabled group in the above factories, which suggests that neither of the two factories intensively studied were special cases.
Finally, we have the important observation that $\frac{3}{8}$ the mean percentage of time at risk lost through ? sickness absence by a group of certified men in $\vec{F}$ three factories did not exceed 5 per cent. of their maximum working time and did not fall below 3 per cent., while the mean percentage of time at risk lost through sickness absence by control groups of normal workers in these factories did not exceed 5 per cent. and did not fall below 2 per cent.

Opinions of Employers.-Ninety-two replies were received from the questionnaires that were sent to the 150 firms in South Wales. Of these, 44 firms had had experience of employing men with pneumokoniosis.

It would be dangerous to attach too much meaning

\section{TABLE VII}

Frequency Distribution of the Percentage of Time at Risk lost through Unauthorized and Sickness Absence by Men Disabled by PNeumoconiosis and by Control Groups of Normal Workers and of Men OTHERWISE DisAbled in FACTORY 2, JAN. 1 TO JUNE 30, 1948

\begin{tabular}{|c|c|c|c|c|c|c|c|c|c|c|}
\hline \multirow{2}{*}{$\begin{array}{l}\text { Percentage } \\
\text { of Time at } \\
\text { Risk Lost }\end{array}$} & \multicolumn{5}{|c|}{ Sickness Absence } & \multicolumn{5}{|c|}{ Unauthorized Absence } \\
\hline & $\begin{array}{l}\text { Pneumo- } \\
\text { coniosis } \\
\text { Disabled }\end{array}$ & $\begin{array}{l}\text { Disabled } \\
\text { Controls }\end{array}$ & $\begin{array}{c}\text { Select } \\
\text { Disabled } \\
\text { Controls }\end{array}$ & Controls & $\begin{array}{c}\text { Select } \\
\text { Controls }\end{array}$ & $\begin{array}{l}\text { Pneumo- } \\
\text { coniosis } \\
\text { Disabled }\end{array}$ & $\begin{array}{l}\text { Disabled } \\
\text { Controls }\end{array}$ & $\begin{array}{c}\text { Select } \\
\text { Disabled } \\
\text { Controls }\end{array}$ & Controls & $\begin{array}{c}\text { Select } \\
\text { Controls }\end{array}$ \\
\hline No absence & 15 & 40 & 16 . & 75 & 20 & 17 & 56 & 18 & 76 & 22 \\
\hline 0 & 15 & 40 & 16 & 75 & 20 & 21 & 66 & 23 & 92 & 26 \\
\hline $1-$ & 1 & 2 & - & 4 & 1 & 5 & 6 & 3 & 3 & - \\
\hline $\begin{array}{l}2- \\
3-\end{array}$ & $\overline{1}$ & $\overline{4}$ & 二 & $\begin{array}{l}1 \\
4\end{array}$ & $\overline{1}$ & - & 二 & 二 & $\frac{1}{2}$ & - \\
\hline 4 & 1 & $\begin{array}{l}4 \\
2\end{array}$ & 二 & 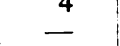 & 1 & 二 & 二 & - & 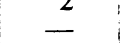 & 二 \\
\hline $5-$ & $i$ & - & - & 3 & 1 & - & - & - & - & - \\
\hline $6-$ & - & 2 & 1 & 1 & - & - & - & - & - & - \\
\hline 7- & 1 & 5 & 3 & 2 & - & - & - & - & - & - \\
\hline${ }_{0}^{8-}$ & - & 1 & - & 1 & - & - & - & - & - & - \\
\hline $\begin{array}{c}9- \\
10-\end{array}$ & $\overline{4}$ & $\overline{7}$ & $\overline{3}$ & 1 & 1 & - & - & - & - & - \\
\hline $15-$ & $\stackrel{4}{-}$ & 7 & $\begin{array}{l}3 \\
3\end{array}$ & $\frac{1}{2}$ & $\overline{1}$ & 二 & 二 & 二 & 二 & - \\
\hline $20-$ & - & 1 & - & 2 & 1 & - & - & - & - & - \\
\hline $25-$ & 1 & 1 & - & - & - & - & - & - & - & - \\
\hline $30-$ & 1 & - & - & - & - & - & - & - & - & - \\
\hline $35-$ & - & - & - & - & - & - & - & - & - & - \\
\hline $40-$ & - & - & - & - & - & E & E & - & - & - \\
\hline $50-$ & 三 & E & - & - & E & E & E & 二 & 二 & 二 \\
\hline $55-$ & - & - & - & - & - & - & - & - & 一 & 二 \\
\hline $60-$ & - & - & - & 1 & - & - & - & - & - & - \\
\hline 65- & - & - & - & - & - & - & - & - & - & - \\
\hline No. of Men & 26 & 72 & 26 & 98 & 26 & 26 & 72 & 26 & 98 & 26 \\
\hline Mean & $5 \cdot 15$ & $5 \cdot 02$ & $4 \cdot 52$ & $2 \cdot 31$ & $2 \cdot 22$ & $0 \cdot 39$ & $0 \cdot 24$ & $0 \cdot 35$ & $0 \cdot 27$ & $0 \cdot 12$ \\
\hline Quartile & $7 \cdot 5$ & $8 \cdot 0$ & $7 \cdot 0$ & $1 \cdot 0$ & $1 \cdot 0$ & $1 \cdot 0$ & $1 \cdot 0$ & $1 \cdot 0$ & $1 \cdot 0$ & $1 \cdot 0$ \\
\hline $\begin{array}{l}\text { Percentage } \\
\text { with }\end{array}$ & & & & & & & & & & \\
\hline Absence & $42 \cdot 3$ & $44 \cdot 4$ & $38 \cdot 5$ & $23 \cdot 5$ & $23 \cdot 1$ & $34 \cdot 6$ & $22 \cdot 2$ & $30 \cdot 8$ & $22 \cdot 4$ & $15 \cdot 4$ \\
\hline Absences & 15 & 43 & 15 & 32 & 7 & 10 & 20 & 12 & 31 & 3 \\
\hline
\end{tabular}




\section{TABLE VIII}

Frequency Distribution of Percentage of Time at RISK LOST THROUGH UNAUTHORIZED AND SICKNESS ABSENCE BY EX-MINERS NOT DISABLED BY PNEUMOCONIOSIS AND BY A CONTROL Group OF NORMAL WORKERS IN StORe Depot, JAN. 1 - June 30, 1948

\begin{tabular}{|c|c|c|c|c|}
\hline \multirow{2}{*}{$\begin{array}{c}\text { Percentage of } \\
\text { Time at Risk } \\
\text { Lost }\end{array}$} & \multicolumn{2}{|c|}{ Sickness Absence } & \multicolumn{2}{|c|}{$\begin{array}{l}\text { Unauthorized } \\
\text { Absence }\end{array}$} \\
\hline & Ex-Miners & Controls & Ex-Miners & Controls \\
\hline No absence & 32 & 30 & 30 & 27 \\
\hline 0 & 32 & 30 & 37 & 32 \\
\hline $1-$ & - & 1 & 1 & 5 \\
\hline $2-$ & 1 & 2 & 1 & 2 \\
\hline $\begin{array}{l}3- \\
4\end{array}$ & 1 & 1 & 1 & 2 \\
\hline $\begin{array}{l}4- \\
5-\end{array}$ & 二 & $\overline{1}$ & - & - \\
\hline $6-$ & 2 & 1 & - & 二 \\
\hline 7- & - & 1 & - & - \\
\hline${ }^{8-}$ & - & - & - & - \\
\hline $10-$ & 1 & $\overline{3}$ & E & E \\
\hline 15 & - & 1 & - & - \\
\hline $20-$ & - & - & 1 & - \\
\hline $\begin{array}{l}25- \\
30-\end{array}$ & 1 & - & - & - \\
\hline 35 & - & 二 & 二 & E \\
\hline $40-$ & - & - & - & - \\
\hline $45-$ & - & - & - & - \\
\hline 55- & E & $\bar{z}$ & 二 & - \\
\hline 60 & - & - & - & - \\
\hline 65- & - & 一 & - & - \\
\hline $\begin{array}{l}70- \\
75-\end{array}$ & - & 一 & - & - \\
\hline 80 & 1 & - & - & - \\
\hline Total & 41 & 41 & 41 & 41 \\
\hline $\begin{array}{l}\text { Mean } \\
\text { Upper Ouar- }\end{array}$ & $4 \cdot 48$ & $2 \cdot 00$ & 0.91 & 0.56 \\
\hline tile $\quad .$. & $.1 \cdot 0$ & $2 \cdot 00$ & $1 \cdot 0$ & $1 \cdot 0$ \\
\hline $\begin{array}{l}\text { Percentage } \\
\text { with Absence }\end{array}$ & $22 \cdot 0$ & $26 \cdot 8$ & $26 \cdot 8$ & $34 \cdot 1$ \\
\hline Absences ... & 12 & 15 & 19 & 33 \\
\hline
\end{tabular}

to the replies to the questionnaire. It is probable that many of the employers had never before considered their disabled employees to be a separate group. Their natural reaction to a request to do so, was to say that the disabled men were "quite satisfactory workers." Where the employer already had an opinion on this matter, his opinion was expressed in a more definite way.

The general tenor of the employers' opinions was found to be favourable. Employers were almost unanimous in the belief that, given certain conditions, disabled men were satisfactory workers. The conditions considered to be necessary were (i) that work must not involve heavy lifting; (ii) that there must be good ventilation in the shop; (iii) that heat, dust, damp, or fumes are undesirable.

Some quotations extracted from the replies to the questionnaire are given below, under the following headings: (a) comparison with normal workers; (b) loss of time by disabled men; (c) types of employment suitable for disabled men.

(a) A factory at Carmarthen employing 12 certified and 8 uncertified disabled men on general labouring duties:

"In the main, these men compare favourably with normal workers where employed in a dry atmosphere."

A factory at Pontypridd employing 9 certified and 1 uncertified disabled men on general factory operations:

"They compare very favourably. The employees concerned are industrious men, diligent, and have adapted themselves well to the various occupations which they have been set."

A factory at Hirwaun employing 7 disabled men as store-keepers, etc.:

"Favourable, i.e. the seven men working here have been placed where their particular disability would least affect them; also they are not severe cases."

A factory at Swansea employing 4 certified and 3 uncertified disabled men as general labourers and factory cleaners:

“ They compare very favourably with normal workers. General opinion held by foremen of departments where these men are employed, is that they are good, willing workers, and that their disability does not interfere with the execution of duties. With the exception of three silicotics (two of whom are certified) who are more lethargic, all are equal to other employees doing similar work."

A factory at Treforest employing 3 certified and 1 uncertified disabled men as store-keepers and general labourers:

"They perform ordinary duties quite as efficiently as normal workers. The greatest handicap is that they are not able to lift any heavy weight, or even material weighing over a half-hundredweight."

A factory at Dinas employing 5 disabled men:

"Our observations from a limited experience would show that such cases are indistinguishable from normal workers employed upon light work and of temperamental equality. We have found that the incidence of absenteeism of a good type of man of these classes is no greater than any other worker, that he can perform any work which does not involve close contact with smoke or 
fumes, or the bending and stooping involved in the lifting of heavy weights. We have further found it to be helpful that such men be offered work of such a nature and in such a manner that attention is not unduly drawn to any sense of a disability."

A factory in Porth employing 3 certified disabled men:

" The men referred to above are employed on machines which require standing up for eight hours a day, but no amount of physical strength. We would like to say most emphatically that these men show, in our opinion, a greater amount of keenness and interest in their work than normal men, and are most satisfactory employees in all respects."

(b) A factory at Carmarthen employing 12 certified and 8 uncertified disabled men on general labouring duties:

“ The tendency is definitely more, for these men lose more time than a normal healthy person as far as this factory is concerned."

A factory at Pontypridd employing 9 certified and 1 uncertified disabled men on general factory operations:

"No noticeable difference from the general average. No wanton absenteeism. Average late-coming and sickness."

A factory at Hirwaun employing 7 disabled men as store-keepers, etc.:

" Varies with degree of disability, but generally fair."

A factory at Treforest employing 3 certified and 1 uncertified disabled men as store-keepers and general labourers:

" They perform ordinary duties with practically no loss of time, providing they are kept on light work. Any undue exertion will cause them to lose one or more days. Their record as far as absenteeism is concerned appears quite favourable, beside that of any of our other male employees. The time lost is practically nil."

A factory at Porth employing 3 men certified as cases of pneumoconiosis:

" In our experience, these men have never been late or guilty of wanton absenteeism. The only observation on this point is that if they do fall ill with ordinary colds, influenza, etc., they are absent from work for a much longer period than normal workers."

(c) Although the opinion of employers about what is suitable work for men disabled by pneumokoniosis is not necessarily medically valid, it is none the less of interest to record some of their opinions $\frac{\pi}{\pi}$ as examples of the attitude of some potential? employers.

A factory at Carmarthen employing 12 certified and 8 uncertified disabled men on general labouring $\frac{C}{C}$ duties:

" The most suitable employment, in our opinion, is in a dry atmosphere where not too much movement is required and the handling is not of a heavy nature. We find that their opinion of what work they can do varies $\overrightarrow{0}$ considerably. Some appear to work satisfactorily in allkinds of conditions, whereas others cannot, or will not, $\vec{\omega}$ put themselves out. I believe a number could be mores gainfully employed if they could get over the thought that they are permanently ill."

A factory at Aberdare employing 5 certified disabled men:

" To be engaged on work:- (a) not heavy; (b) not? exposed; (c) not dusty. Generally speaking, more thanusual normal employment procedure has to be adopted to suit specific cases."

A factory at Porth, employing 4 disabled men $\frac{\overrightarrow{0}}{\overrightarrow{0}}$

" Mobile employment or some movement desirable. Long runs of same type of work desirable."

A factory at Treforest employing 1 certified and 2 uncertified disabled men:

"We think that these types of workers want to be living near their work, and should not do long, damp3 journeys."

A factory at Pontypridd employing 1 man with pneumokoniosis:

" In this branch of industry (fancy goods), it should beं possible to employ these men on general factory work on winding machines, and if possessing natural dexterity on knitting looms and other similar machines. Age, of course, plays an important part in deciding these queso tions. Our man is young, about 24 years old. An oldP man, with probably more infection, would not give suck? a favourable picture."

A factory at Treforest employing 3 certified and 1 uncertified disabled men as store-keepers an general labourers:

"Our experience as far as most suitable types of employment is concerned is limited, but we have founce that, given reasonably good ventilation in a shop, and? providing that the amount of lifting is not excessive? these men should be able to tackle most types of factory work."

Some further evidence on the comparative efficiency of disabled men was collected fron 
progress reports kept by a firm at Treforest. In this firm annual reports are made on each worker by his foreman and these reports are checked by the senior foreman. Marks are awarded under seven different headings:-

$\begin{array}{lllll}\text { 1. } & \text { Accuracy } & . . & \ldots & 10 \text { marks } \\ \text { 2. } & \text { Efficiency } & . . & \ldots & 10 \text { marks } \\ \text { 3. } & \text { Industry } & . & \ldots & 10 \text { marks } \\ \text { 4. } & \text { Adaptability } & \ldots & 10 \text { marks } \\ \text { 5. } & \text { Loyalty } \ldots & \ldots & 10 \text { marks } \\ \text { 6. } & \text { Improvement } & \ldots & 10 \text { marks } \\ \text { 7. } & \text { General Impressions } & 40 \text { marks }\end{array}$

Total: 100

These reports are used as a basis for promotion. The marks awarded to 24 disabled men and to 24 men in a control group were obtained. The results are interesting but inconclusive; the small numbers concerned and the subjective nature of these estimates obviously make caution imperative.

It was found that the average mark given to the control group was 68.6 and to the disabled group 65.5. There was a considerable difference in the distribution of the marks given under each heading and this distribution is shown in Table IX.

\section{TABLE IX}

Distribution of Marks for Progress of Men Disabled by Pneumoconiosis and of Normal Controls

\begin{tabular}{|c|c|c|}
\hline Range of Marks & $\begin{array}{l}\text { Percentage of } \\
\text { Disabled Men in } \\
\text { Each Range }\end{array}$ & $\begin{array}{l}\text { Percentage of } \\
\text { Control Group in } \\
\text { Each Range }\end{array}$ \\
\hline $\begin{array}{l}\text { 1. Accuracy } \\
\begin{array}{l}1-5 \\
6-10\end{array}\end{array}$ & $\begin{array}{l}75 \\
25\end{array}$ & $\begin{array}{l}58 \\
42\end{array}$ \\
\hline $\begin{array}{l}\text { 2. Efficiency } \\
\begin{array}{r}1-5 \\
6-10\end{array}\end{array}$ & $\begin{array}{l}64 \\
36\end{array}$ & $\begin{array}{l}37 \\
63\end{array}$ \\
\hline $\begin{array}{l}\text { 3. Industry } \\
\begin{array}{l}1-5 \\
6-10\end{array}\end{array}$ & $\begin{array}{r}3 \\
97\end{array}$ & $\begin{array}{l}17 \\
83\end{array}$ \\
\hline $\begin{array}{r}\text { 4. Adaptability } \\
1-5 \\
6-10\end{array}$ & $\begin{array}{l}66 \\
34\end{array}$ & $\begin{array}{l}58 \\
42\end{array}$ \\
\hline $\begin{array}{r}\text { 5. Loyalty } \\
\qquad \begin{array}{r}1-5 \\
6-10\end{array}\end{array}$ & $1 \overline{100}$ & $\begin{array}{r}5 \\
95\end{array}$ \\
\hline $\begin{array}{r}\text { 6. Improvement } \\
1-5 \\
6-10\end{array}$ & $\begin{array}{l}79 \\
21\end{array}$ & $\begin{array}{l}54 \\
46\end{array}$ \\
\hline $\begin{array}{r}\text { 7. General } \\
20-30 \\
31-40\end{array}$ & 100 & $\begin{array}{l}55 \\
45\end{array}$ \\
\hline
\end{tabular}

The figures in Table IX are presented for what they are worth. If any conclusion can be drawn from them it is that, on this evidence, the disabled men in the factory seemed to be less accurate, efficient, adaptable and capable of improvement than those in the control group, but were more loyal and industrious.

\section{ConClusions}

Our investigation provides no information about the men more disabled by pneumoconiosis as they will not presumably be found in employment in factories. Nor does it permit us to say anything about the performance of the less disabled men when employed in any other circumstances than in light factory work. In light factory employment, however, it would appear from the quantitative and qualitative evidence presented that there is no reason to suppose that a group of men with pneumokoniosis would have much, if any, greater absence than a group of normal men. This conclusion, of course, may be subject to some considerable margin of error, for men with pneumoconiosis vary greatly as far as their physical disability is concerned. This fact makes generalization about the absence performance of the population of pneumoconiosis cases, as a whole, dangerous. This is particularly true when the small scope and selective nature of the data used in this paper are taken into account.

More confidence can be placed in the assertion that a group of less seriously disabled men will not be absent to such an extent that they will be differentiated by employers in this respect from the rest of their workers. This last conclusion is confirmed by the results of the employment questionnaire.

\section{SUMmaRY}

The efficiency of ex-miners disabled by pneumoconiosis who were employed in light factory industry was assessed by comparing their absence records with those of control groups of normal workmen; and also by analysing the opinions of employers about the performance of the disabled men.

The absence records in two factories were studied intensively. In one of these factories which employed 37 disabled men in 1946, 60 in 1947 and 69 in 1948, it was found that both the sickness and the unauthorized absence of the disabled men did not differ significantly from the absence records of the control groups in these years. In the other factory, which employed 26 disabled men in 1948, a similar result was obtained. Absence records for disabled men in a third factory were similar to those 
in the two studied intensively and this suggested that the latter were representative.

The conclusion was reached that it is improbable that a group of pneumoconiosis cases who obtain employment in light industry could or would be distinguished by their employers, as far as absence is concerned, from other normal workers.

The opinions of the employers about the performance of the disabled men in light industry were, on the whole, very favourable.
I wish to acknowledge the very great help and co-opera- $\frac{3}{8}$ tion which I received, when obtaining the absence data, 0 from the personnel managers of all the factories studied. $\Rightarrow$ : I am also indebted to Mr. Pierre Gutman of Columbiac University and to Mr. P. D. Oldham of the Pneumo coniosis Research Unit for their help with the statisticale analyses used in this paper.

REFERENCES

Pitman, E. J. G. (1937). Supp. J. Roy. Statist. Soc., $\varrho$ 4, 119.

"Social Survey" (1946). Unpublished.

Stewart, A. M. (1948). Brit. J. industr. Med., 5, 120.

.

